\title{
Application of Electron Microscopy on Volcanic Ash
}

\author{
A. L. Romano ${ }^{1 *}$, E. I. Rovere ${ }^{2}$ \\ ${ }^{1}$ Servicio Geológico Minero Argentino (SEGEMAR) INTEMIN, Buenos Aires, Argentina. \\ ${ }^{2}$ Servicio Geológico Minero Argentino (SEGEMAR) IGRM, Buenos Aires, Argentina. \\ *Corresponding author: andrea.romano@segemar.gov.ar
}

This contribution is the result of a research project on volcanic ash from eruptions that affected the territory of Argentina. The study of volcanic ash is essential for knowledge and research in multiple disciplines, particularly in: Health, Industry, Air Navigation, Mining, Water Supply, Soils and Environment. The instrumentation used was Philips XL30 ESEM Scanning Electron Microscope and EDAX Microwave Probe in volcanic originated particles [1]. This method advantages are of fast morphological and compositional observation, mineralogical and crystal assembly visualization, detection of mineral alteration. Surface microtextures, grain size and semi quantitative chemical composition are measured, this contribute to the characterization of volcanic episodes, and help to forecast possible future eruptions.

The term 'tephra' refers to all sizes of ejecta produced during explosive volcanism. Single grains smaller than $2 \mathrm{~mm}$ in size are termed 'volcanic ash' and those below $64 \mu \mathrm{m}$ are 'extremely fine ash' and fragments of 2-64 $\mathrm{mm}$ are termed 'lapilli'. Volcanic ash plumes from eruptions of the Andean volcanic arc comprise fragments of vitroclasts, lithics, crystals and minerals. 'Microtephra' and 'cryptotephra' are terms used in tephrochronology to describe horizons with dispersed ash grains that are too tiny to be seen by the naked eye, usually identified by laboratory analysis of soils and sediments. Here we refer to individual ash, aggregates or airborne fragments as 'grains' or 'particles. Grain lengths or diameters correspond to the long axis of a grain as it appears under the optical or electron microscope. PM10 and PM 2.5 refer to airborne particles that pass through the inlet of air sampling equipment with a 50\% collection efficiency at $10 \mu \mathrm{m}$ and $2.5 \mu \mathrm{m}$, respectively.

Ashfall from volcanoes [2] Quizapu (1932), Hudson (1991), Copahue (2000-2018), Chaitén (2008), Puyehue / Cordón Caulle (2011) and Calbuco (2015) were analyzed.

High silica content volcanoes (i.e. Chaitén volcano 2008) produce higher volumes of fine ash $(<63$ $\mathrm{mm})$ than basaltic eruptions $\left(\mathrm{SiO}_{2}<50 \%\right)$ (i.e. Kilauea Volcano). Rhyolitic eruptions ousted about 30 to $50 \%$ silica during the first ash explosions, compared with 1-4\% during the later stages. This fine ash was easily transported by the wind over long distance, evidenced in $90 \%$ of the tephra fall deposits in the stratigraphic levels of the Patagonian "estepa" (towns of Esquel, Comallo, Ingeniero Jacobacci, etc.). Fine ash from high explosivity index (VEI) volcanoes have large specific surface evidenced on their micro-textures, this can explain how toxic volatiles such as fluoride can be adsorbed into microscopical vesicles and produce later environmental impacts on water and soils, affecting human and animal health [3]. The study of particles by mineralogical and chemical studies (polarization microscope and SEM-EDAX analysis) before and after following the protocol for volcanic ash-leachate analysis are the most effective procedures in health (epidemiology) and environmental hazard studies.

\section{Advantages and Conclusions of the use of electronic microscopy in volcanic ash.}

The determination of particle size smaller than $10 \mu \mathrm{m}$ have been determinants for epidemiological studies in ashes and particles (PM 4, PM 2.5). The analysis of EDAX in ashes with $\mathrm{SiO}_{2}>65 \%$ of the eruption of the Chaitén volcano (see figure 1) has complementary research to determine hazardous cristobalite crystals (Ing. Jacobacci, Río Negro). Electron microscopy analysis in particles 
of the lahar (volcanic rock and mudflow) that severely destroyed critical infrastructure in Villa Catedral ski resort (Bariloche, Argentina ) in 2015 [4], allowed to demonstrate the origin of the ash accumulation from Calbuco sub-plinian eruption.

\section{The SEM EDAX studies will determine volcanic hazards factors in:}

-Health: respiratory, ocular, dermatological, anaphylactic hypersensitivity, coronary diseases. Installing dust sensors, samplers and monitoring instruments [3]. (Dust Track, Minivol, other recipients) are essential to continue studies for statistical determinations.

-Aircraft and Airports advisory system [5]: coordination in the Early warning system, flight planning, Airports runway sanitation. (VAAC, Volcanic Ash Advisory Center).

The authors acknowledge SEGEMAR and Dr. Andrés Pinto for his many useful discussions and contributions to this work.

References:

[1] A.L. Romano, E. Rovere, R. Violante, S. D'Ambrosio. 18 ${ }^{\circ}$ CGA, Actas CD-S10C: 586. Neuquén. (Publisher AGA, Neuquén, Argentina).

[2] E.I. Rovere, R. Violante, E. Rodriguez, A. Osella, M. De la Vega. LAJSBA 19 (2) 2012, 125149. AAS ISSN 1669-7316.

[3] W. Mueller, Horwell CJ, Apsley A, Steinle S, McPherson S, Cherrie JW, Galea KS. I.J.H.E.H. (2010), https://doi.org/10.1016/j.ijheh.2018.03.012

[4] S. M. Uber, E. Rovere, A.L. Romano, Y. Zapata, E. Detang. Foro Internacional: Los Volcanes y su Impacto, Arequipa, Perú, 2018. 80-82. OVI - INGEMMET

[5] S. Castro Godoy, E. Rovere. 18 CGA, Actas CD-S10C, 554:2011. Neuquén, Argentina.

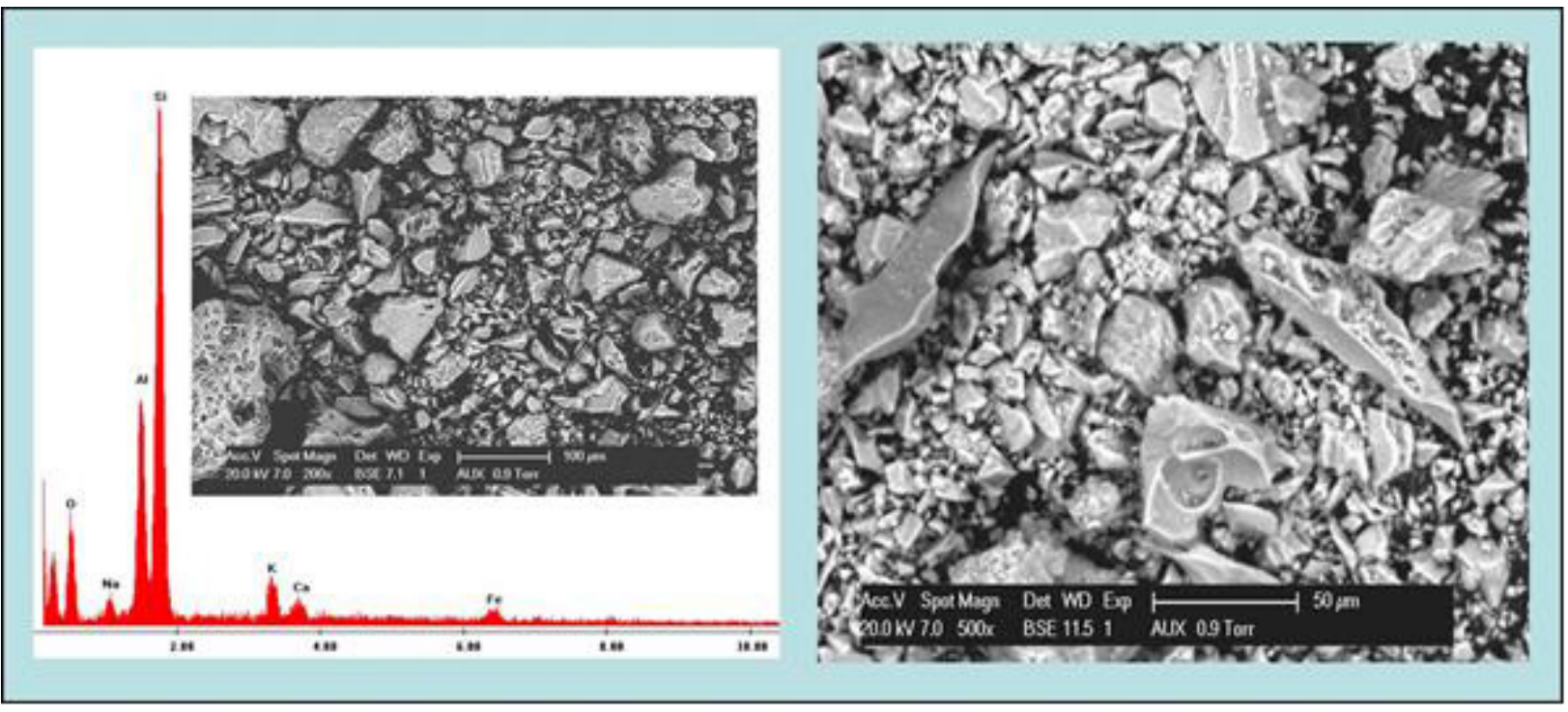

Figure 1. Photomicrograph and spectrogram of vitric ash of Chaitén volcano. High silica content evidence the presence of Crystobalite. Sharp edged shards show the abrasive feature of the tephra. 